\title{
The use of laser scanning in the survey of the postern of the Kłodzko Fortress
}

\author{
Piotr Gleń \\ https://orcid.org/0000-0002-2975-408X \\ p.glen@pollub.pl
}

Karol Krupa

https://orcid.org/0000-0002-7313-4080

k.krupa@pollub.pl

Faculty of Civil Engineering and Architecture, Lublin University of Technology

\begin{abstract}
Summary: This article presents the significance of laser scanning as a method of acquiring spatial data and the significance of this method during the process of survey of historic monuments. The authors of the paper focus on the survey of the postern located under the eastern slope of the Kłodzko Fortress and connecting the town with the upper levels of the fortification. With the use of laser scanning, a three-dimensional image of the postern was obtained. Based on the results of measurements, it is possible to specify the dimensions of tunnel elements which are difficult to measure, such as the buried fragment of the postern and the height of the embankment located above the tunnel. The research conducted by the authors of the article has been juxtaposed with the available archival materials concerning this part of the Kłodzko Fortress.
\end{abstract}

Keywords: fortress, Kłodzko, postern, fortification, 3D scanning, cloud of points, survey

\section{Introduction}

The aim of the conducted research is a survey of the Kłodzko Fortress. The research described in this paper focuses on the measurements completed in 2019 by a team from the Faculty of Civil Engineering and Architecture at the Lublin University of Technology concerning the inaccessible part of the facility, that is the postern. The research includes measuring of the entire site. The article presents detailed results of measurements and comparative analysis based on available plans of the postern made available by the Berlin Archive. So far, no survey of the postern has been made, which proves the uniqueness of the research conducted by the authors of this publication. From 2016 to the present day, the authors have been carrying out survey works on the entire site using one of the most precise surveying methods - laser scanning [1] (Fig. 1).

The Kłodzko Fortress erected in the $17^{\text {th }}$ century is one of the best-preserved examples of the Architectura militaris from that period in Poland. It is a part of cultural heritage defined as:

(...) all buildings, earth forms, greenery, obstacles, and transformations of water regime made by man to defend a place against enemy attack, regardless of whether it is a permanent, semi-permanent or field fortification. (...) Historic fortifications are defined as structures erected from the dawn of history until more or less 1957. [2]. "In the last five years of the $20^{\text {th }}$ century an attempt was made to record all of these monuments on the area of Poland. As a result of the studies carried out in several scientific centres with the participation of the Society of Friends of Fortifications, within the National Programme of the Ministry of Culture and Art "Protection and Conservation of Defensive Architecture" (1997 - 1999) the stock of preserved buildings has been identified and documented (...). As a result of the research project (...), 4817 preserved defensive structures (...) were registered, almost all of which were concentrated in 130 complexes. [3]. 
A survey of historic buildings plays a significant role in the process of their protection. The use of laser scanning as a method of obtaining spatial data is one of the most accurate ways to obtain data of the current state of a studied building. It often allows to analyse the progressive degradation in historical tissue.

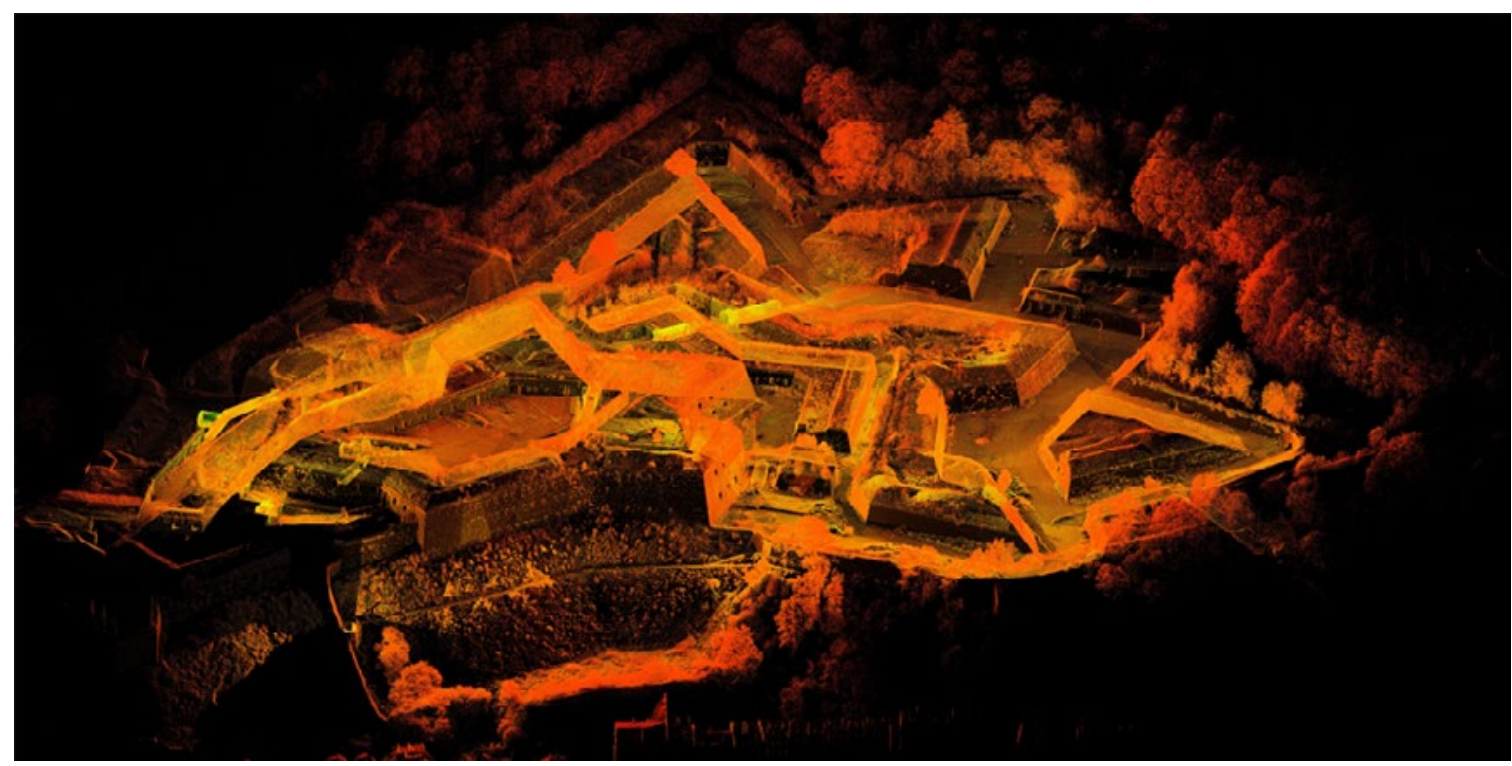

Fig. 1. The image of the Kłodzko Fortress generated with the Leica Cyclone program - the authors' own elaboration

The Kłodzko Fortress is so well-preserved that it is a fascinating research material as a full and rich resource. The survey of such a vast site as the whole fortification complex of the Kłodzko Fortress differs from the method of surveying of a single architectural building. In this particular case, we deal not only with an exceptionally large facility but also with the historical architectural tissue. Therefore, it is important to carry out measurements as accurately as possible, putting emphasis on the destruction or transformation of the elements that have occurred over the years. Through analyses allowing for the determination of changes taking place in a building, it is possible to precisely determine the degree of degradation of the historic tissue and secondary layers appearing in it. Thanks to the survey conducted by the scientific team from the Lublin University of Technology, another database of digital record measurements, i.e. a cloud of points, is obtained every year. The authors of the paper focus on the analysis of measurements of the postern connecting the upper levels of the Kłodzko Fortress with the town from the eastern side due to the fact that so far this element of the fortress has not been thoroughly studied and surveyed. Laser scanning used in the work on the above-mentioned building makes it possible to obtain an accurate survey note, taking into account the detailed measurements of the geometry of walls, damages and earth embankments above the postern. The huge database of spatial measurements is limited to a minimum by the measurement error and ensures maximum detail of the measured architectural details. The measurements of the inaccessible underground part of the postern as a cloud of points have been juxtaposed with the archival materials made available by the facility administrators. The use of such a measurement technique makes it possible to generate spatial data which includes measurement results in the form of a three-dimensional model of a building. Then, the acquired data are used to create a very detailed documentation in the form of numerical CAD [4]. Nowadays, the use of BIM technology, thanks to which we obtain a three-dimensional survey model, is becoming increasingly popular. With the use of appropriate software, it is extremely useful in subsequent conservation works [1].

\section{Kłodzko Fortress - general information}

Kłodzko Fortress is a complex of fortifications from the $17^{\text {th }}$ and $18^{\text {th }}$ centuries. The town of Kłodzko is located in the Lower Silesia Voivodeship, in Kłodzko Poviat, in the north-eastern part of the Kłodzko Valley. At the 
place of the fortress, there was a medieval castle in the $14^{\text {th }}$ century, which was later rebuilt in the $16^{\text {th }}$ century $[5,6]$. In 1622, modernisation works were undertaken on the fortifications and the castle itself due to the earlier artillery siege [7]. After Frederick the Great conquered the castle, it was rebuilt under the responsibility of General Gerhard Cornelius Walrave. At that time, a new fort, named Owcza Góra, was built on a neighbouring hill [8]. Due to changing defensive conditions, the fortification was transformed over the following years. The dynamic development of military techniques caused that the Kłodzko Fortress quickly lost its military significance. During World War II the fortress housed a prison and SS headquarters [9]. After the war, an AEG arms factory from Łódź was located there [10]. Then, until 1957, the facility was owned by the local military stationed there. Afterwards, it fulfilled economic functions [11]. The building was entered in the Register of Monuments in 1960 and was also opened to the public [12]. To this day, the building has been used for both tourist and museum purposes.

\section{The research method - Terrestrial Laser Scanning (TLS)}

The basis for the survey conducted by the team from the Faculty of Civil Engineering and Architecture of the Lublin University of Technology at the Kłodzko Fortress is a cloud of points obtained using 3D scanning. The 3D scanner Leica C10 (Fig. 2) was used for field work, while the subsequent processing of the acquired spatial data was performed with the use of Cyclone software by Leica. Terrestrial laser scanning is one of the most accurate measurement techniques used in works related to the survey of historic buildings [13]. This technology obtains spatial data on the scanned building (its shape, texture, colour, dimensions, distance, etc.) with the use of a laser beam transmitted from the measuring device. A survey documentation is of key importance in subsequent conservation works on a historic building [14]. Thanks to the scanning technology, it is possible to survey such elements as e.g.: tunnel geometry, location of survey openings, or the state of structural elements [15]. The authors of the research, thanks to the application of the described measurement technology, obtained a detailed three-dimensional model of the postern in the form of a cloud of points (Fig.3.). This method allows for an accurate mapping and later comparative analysis with available archival materials or with previously performed scans.
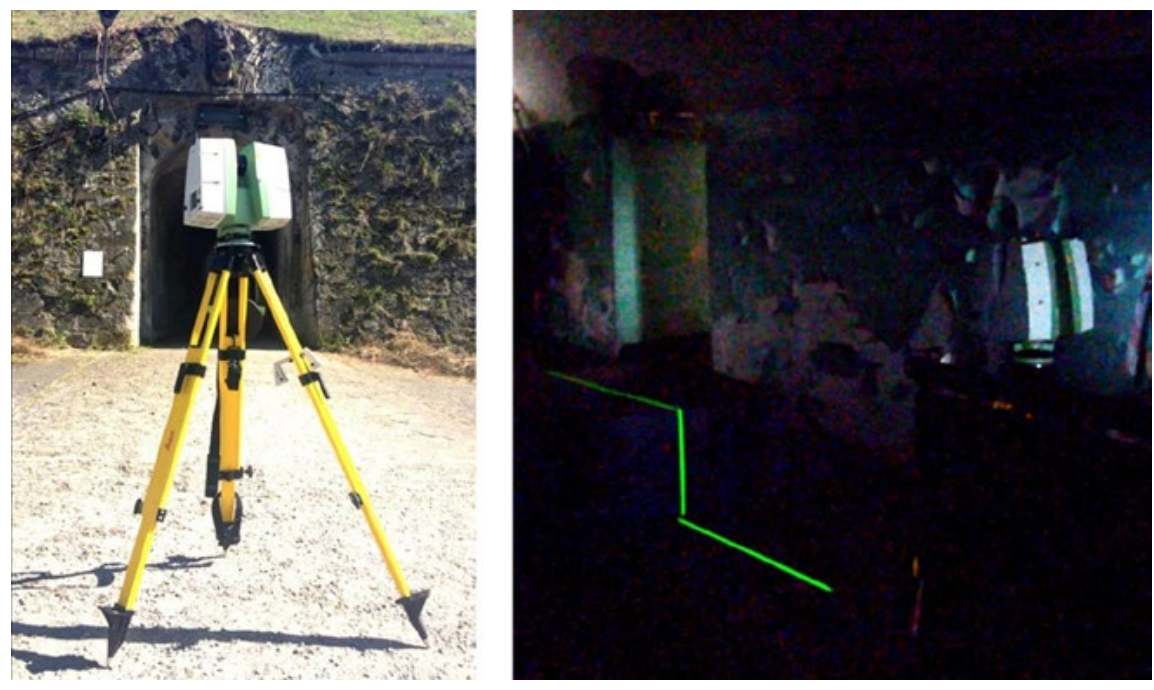

Fig. 2. A Leica C10 scanner - the authors' own photography

The advantage of this measuring technique is both the speed of measurement and the accuracy of the data obtained in this way. This approach is increasingly popular in the case of research related to historic buildings [16]. Laser scanning can be treated as a direct measurement method [17]. The choice of this measurement technology was based on the combination of measurement speed with relatively high quality of the acquired data. In the case of the postern, the generated three-dimensional image enables an accurate analysis of damages, losses and deformations in tunnel construction elements. 


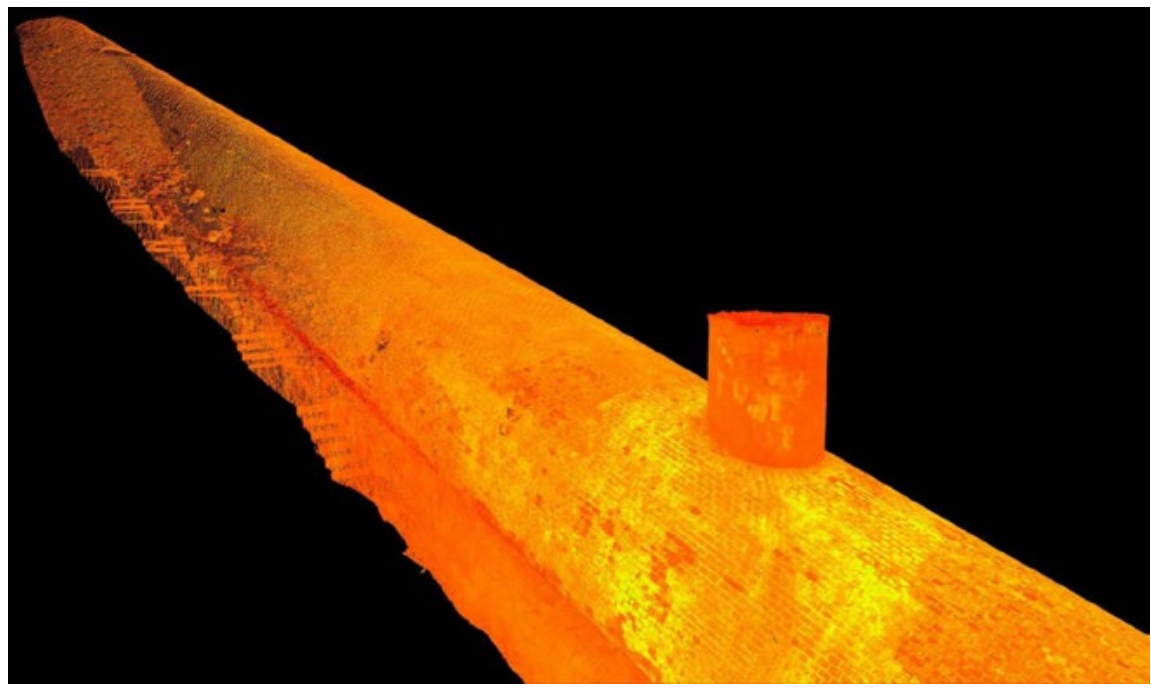

Fig. 3. Three-dimensional view of the postern generated with the Leica Cyclone program - the authors' own elaboration

\section{The survey of the postern}

The postern, originally used to transport ammunition and supplies to the highest levels of the fortress, is located under the eastern slope of the complex. It is difficult to access due to a bricked-up entrance located at a considerable height from the level of the tenement house courtyard on the side of the town and a secondary earth embankment on the side of the fortress. The location of the underground passage is shown on a three-dimensional model of the fortress which also illustrates its structure (Fig. 4). The scale of the underground passage is also presented on the archival map and, for comparison, on the satellite photo of the same part of the fortress (Fig. 5).

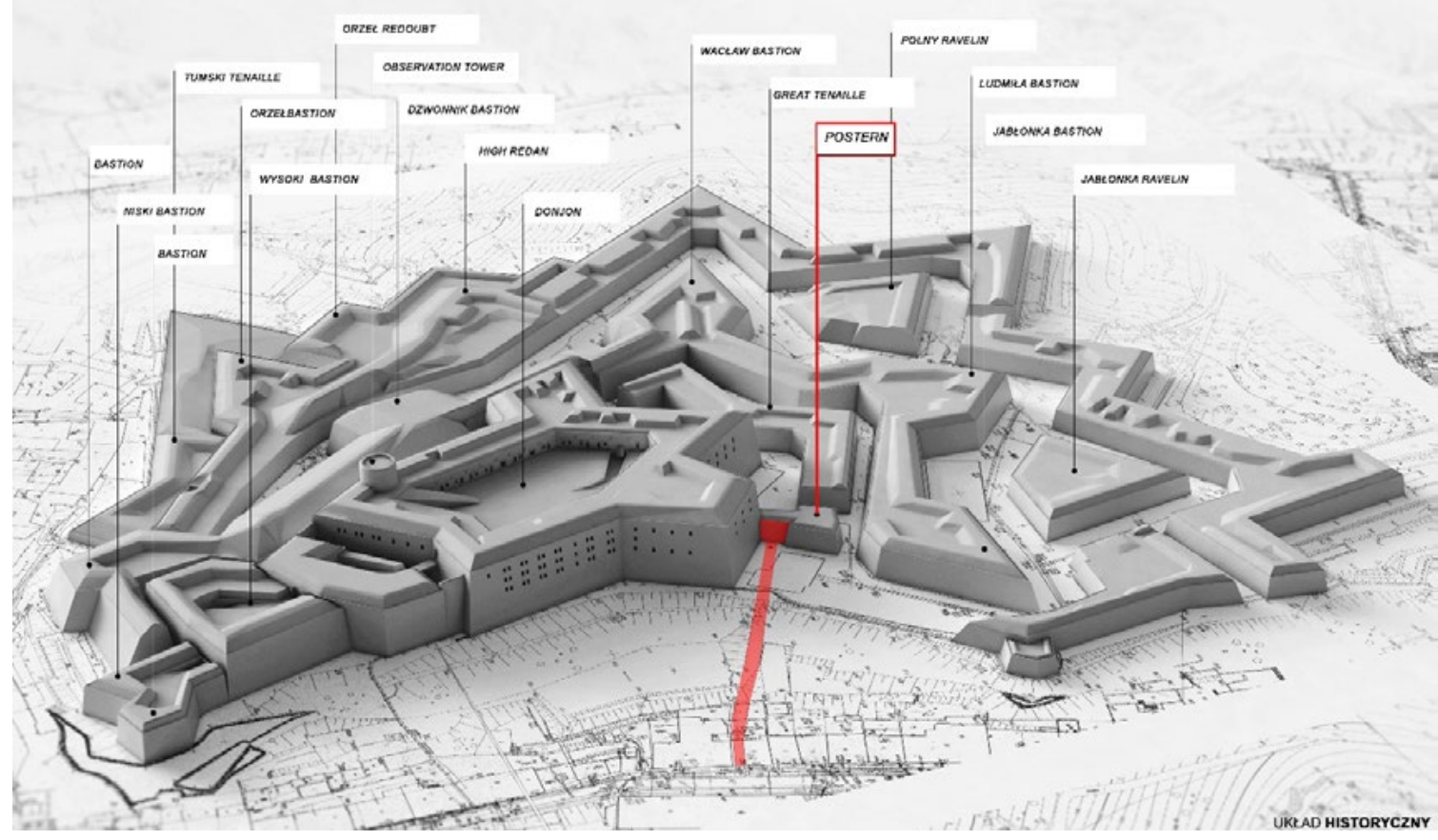

Fig. 4. The location of the postern (red colour) - the authors' own elaboration 
The preparation of the survey documentation will be used in several areas related to the postern. The main aim is to supplement the existing documentation and to enable the use of measurements in the process of adaptation and restoration of the facility for the public use. Previous scanner measurements, made by the authors of the article in 2016, will also serve to prepare technical expertise and documentation of architectural research, by indicating the exact location of the former boiler house building and its impact on the state of the postern.
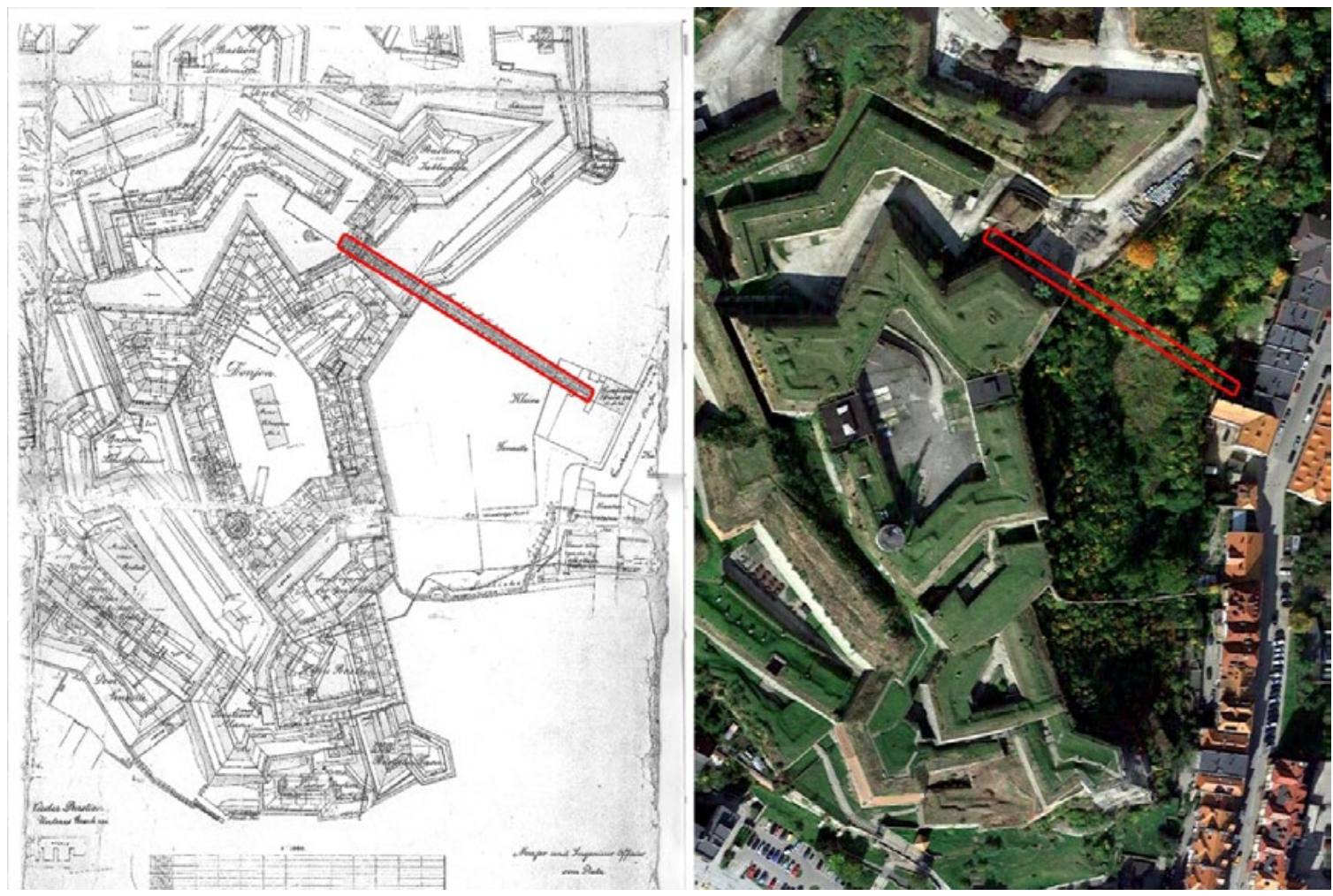

Fig. 5. The location of the postern (red colour) - source: the Berlin Archive (left), authors' own elaboration (right)

In order to obtain an accurate measurement of this unusual structure, it was necessary to scan a fragment of the fortress from its upper parts. Then, the measuring device descended gradually down the slope to the town in order to obtain a profile of the terrain. The next stage was to scan the courtyard of the tenement houses at the entrance to the postern and then to make a hole in the secondary walled-up entrance gate (Fig. 6.). After placing the scanner inside the tunnel, measuring stations were set up one after another in the direction of the driveway of the fortress. This allowed the authors to identify the air vents located in the ceiling and not visible from the outside. The scan of the interior is presented as a cloud of points in Fig. 7. As a result, a very accurate survey note was obtained. Due to this kind of measurement it is possible to estimate the amount of the earth embankment inside the postern from the side of the Great Tenaille. Such an extensive range of scanning also enables us to determine changes in the geometry of the postern or the terrain of the slope. Taking into account the dimensions of the tunnel, it was necessary to take into account variable dimensions of the vault cross-sections, the occurrence of which would be difficult to determine. The use of a scanner made it possible to include the thickness of the embankment along the whole length of the studied structure in the measurements. The analysis of archive materials containing the cross-section via the postern juxtaposed with the cross-section generated on the basis of the conducted measurements makes it possible to show changes in the slope geometry and damages in the tunnel structure.

After combining the scans made during previous measurements, covering the rest of the fortress, a full information was obtained concerning the spatial relations between the postern and the courtyard at Great Tenaille, the levels of the courtyard on the side of the town, as well as the secondary earth embankment inside 
the postern (Fig. 8.). This may allow for the mapping of the original state, as well as securing the existing historic elements in order to protect the historic structure of the analysed facility.
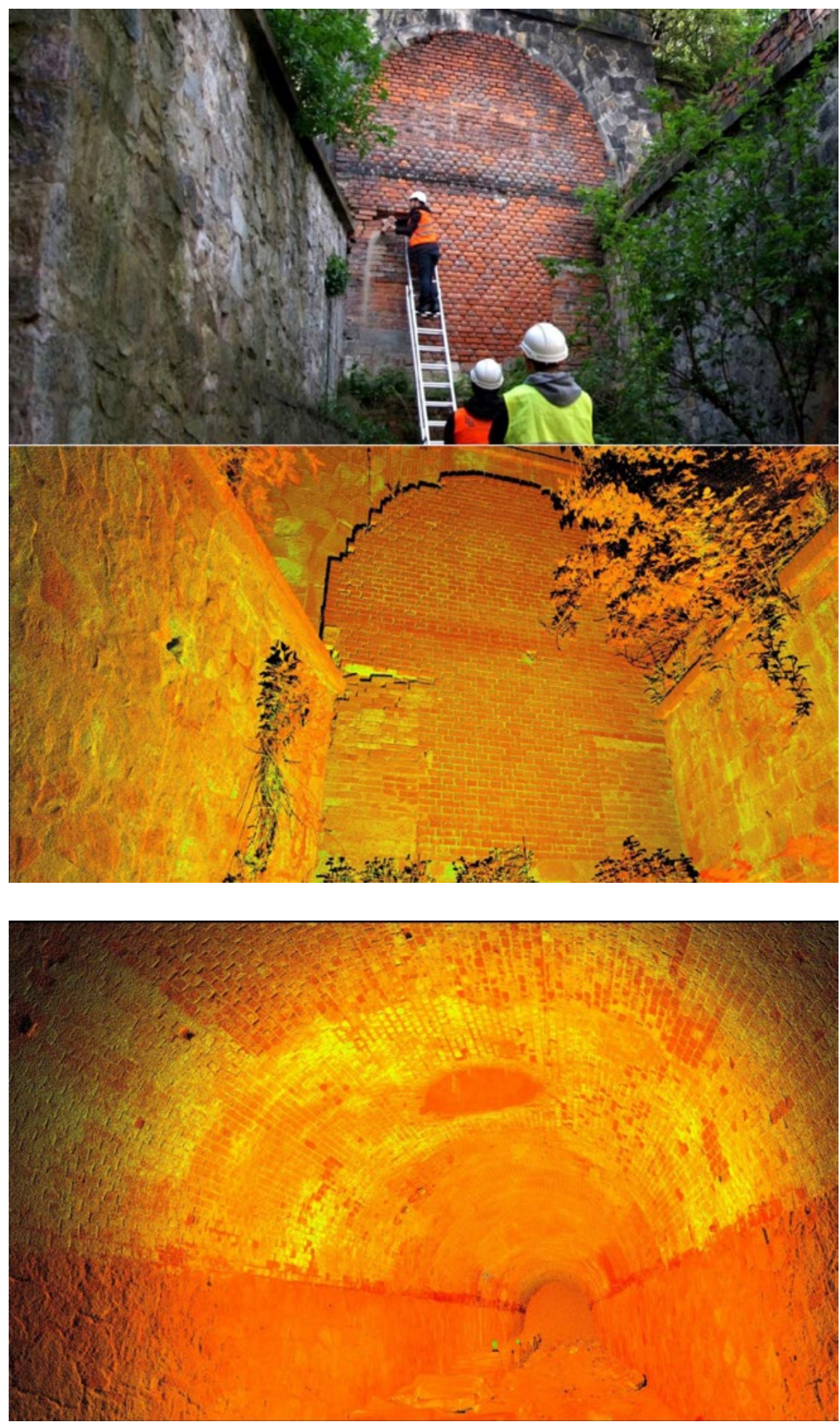

Fig. 6. A photograph from the measurement stage (2019) and a picture of the measurement of the entrance gate to the postern generated with the Leica $\mathrm{Cy}$ clone software - the authors' own elaboration

Fig. 7. A 3D view of the interior of the postern generated with the Leica Cyclone software - the authors' own elaboration 


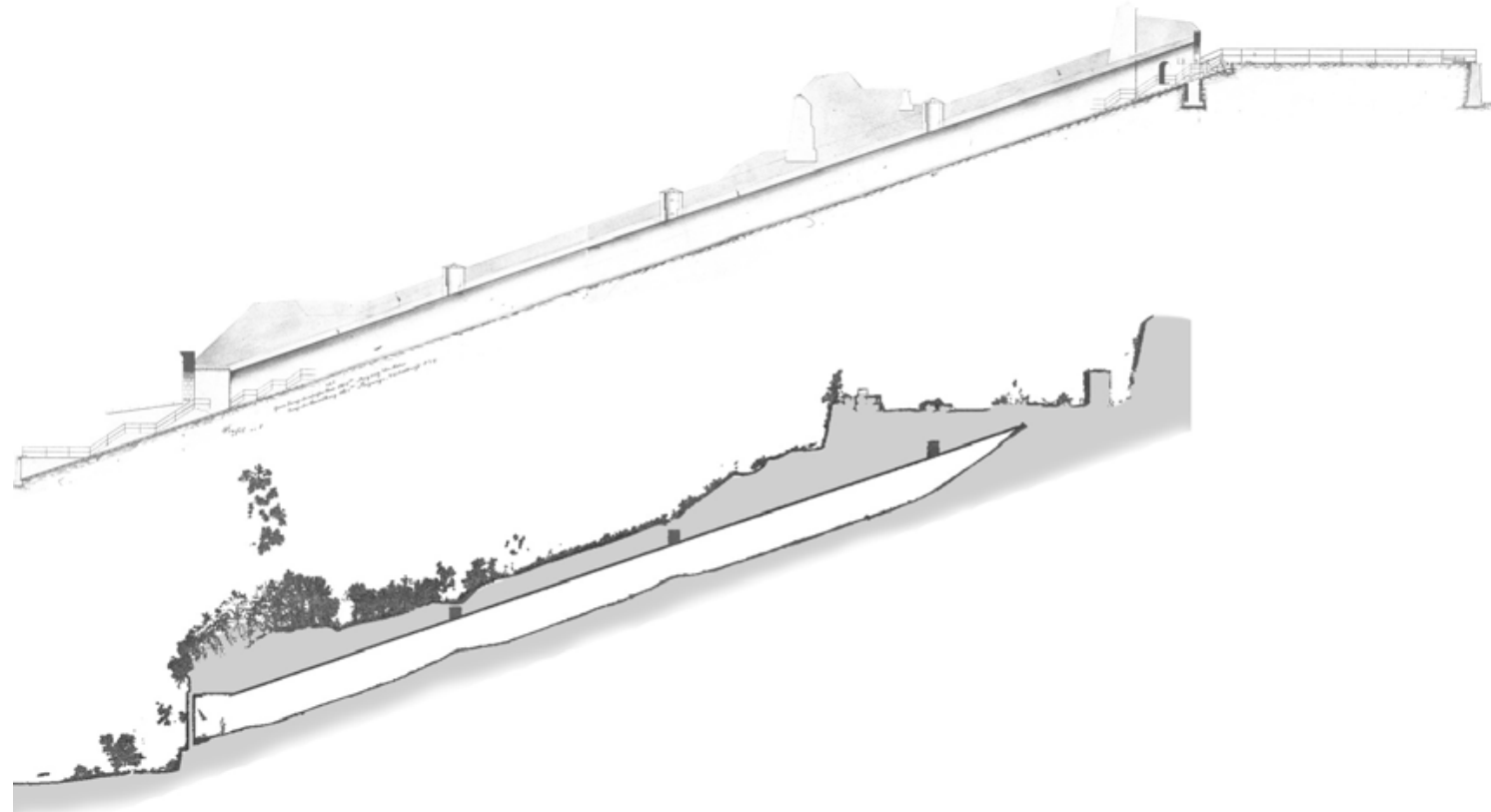

Fig. 8. A cross-section of the postern - at the top, archival drawing from the Berlin Archive made available for the purpose of the research by the administrator of the Kłodzko Fortress, juxtaposed with a result of the laser scanner measurement - the authors' own elaboration

A comparative analysis of the cross-section of the postern shows a change in the geometry of the slope under which the transport tunnel is located. The earth embankment inside the postern is also visible, as well as the expansive greenery covering the eastern slope above the postern. It is also possible to locate the ventilation holes of the passage from the side of the slope.

\section{Conclusions}

Surveys conducted on historic sites are very important in the context of protection of the cultural heritage values. Detailed measurement documentation becomes a necessary element in conservation works aimed at saving the historical tissue of buildings. This paper addresses the issue of the use of modern measurement techniques which enable digital surveying in the form of three-dimensional models. The part of Kłodzko Fortress that has been analysed in this article is a proof of the great extent to which changes can occur in historic structures over the years. As the Kłodzko Fortress is a valuable example of Architectura militaris, all works and activities aimed at increasing its accessibility for visitors should take into consideration archival materials with architectural, conservation and historical background.

On the basis of measurements and conducted research, the technical state of the existing building should be determined, which will provide a basis for adopting an architectural and functional concept. Adaptation of the postern is an interesting design challenge, and the accepted description and completion of the tourist path should be carefully thought out in terms of the introduced content. Reconstructing of the elements and solving of technical problems should be based on materials obtained from the conducted survey. The grounds for all actions should be the need to preserve the historical and cultural values of all elements of the whole fortification complex in Kłodzko. The basis for revitalisation and protection of the heritage should be an accurate and reliable survey of facilities based on modern measurement technologies. 


\section{References}

[1] Piotr Gleń, Karol Krupa, Comparative analysis of the inventory process using manual measurements and laser scanning, Budownictwo i Architektura 18(2) (2019), p. 21-30 accessed: 10.35784/bud-arch.552.

[2] Gruszecki A., Specyfikacja zasobów architektury obronnej w Polsce, ich ochrony i zagospodarowania w: M.L. Lewicka [ed.], Ochrona zabytków architektury obronnej, Giżycko 1997, p. 19.

[3] Kartograficzne udokumentowanie zasobów budownictwa obronnego w Polsce. Połowa XVIII w. - XX w., research project KBN no. 7T07F03610, joint publication under supervision of A. Gruszecki, Warszawa 2007.

[4] Boroń Adam, Rzonca Antoni, Wróbel Andrzej, The digital photogrammetry and laser scanning methods used for heritage documentation (in:) Polskie Towarzystwo Informacji Przestrzennej, Roczniki Geomatyki 2007, Vol. V, book 8, p. 129.

[5] Guerquin B., Zamki Śląskie, 1957.

[6] Broniewski T., Śląsk w zabytkach sztuki, 1963.

[7] Triller E., Rocznik Ziemi Kłodzkiej 1958, Vol. III 1959.

[8] Bukal G., Niderlandyzm w sztuce polskiej, 2000.

[9] Jędrysiak T., Mikos von Rohrscheidt A., Militarna turystyka kulturowa, PWE, 2011.

[10] http://www.dawnekłodzko.pl, accessed: 09.03.2019.

[11] http://www.zamkipolskie.pl, accessed: 09.03.2019.

[12] Decision KL-V-1/61/30 of $13^{\text {th }}$ May, 1960 r. on entry to the Register of Historic Monuments.

[13] Piotr Gleń, Karol Krupa, The use of secondary build-up in historical fabric based on the donjon of Ktodzko Fortress / E3S Web of Conferences - 2018, vol. 49, s. 1-10, DOI: https://doi.org/10.1051/e3sconf/20184900031.

[14] Gleń P., Krupa K. The use of 3D scanning for the inventory of historical buildings on the example of the palace in Snopków. Teka Komisji Architektury, Urbanistyki I Studiów Krajobrazowych, 2020, 15(2). DOI: https://doi.org/10.35784/teka.889.

[15] Michałkowska K. [ed.], Modelowanie i wizualizacja danych 3D na podstawie pomiarów fotogrametrycznych i skaningu laserowego, 2015.

[16] Zapłata R., Pomiar, inwentaryzacja i diagnostyka drewnianej architektury wernakularnej - wybrane zagadnienia zastosowania technologii skanowania naziemnego, Budownictwo i Architektura 14(4), 2015.

[17] Filipowski Szymon, Laser scanning in architectural surveying - popular solutions and proposal for improvement, PUA 1/2018, p. 97.

\section{Wykorzystanie skaningu laserowego przy inwentaryzacji poterny Twierdzy Kłodzko}

Streszczenie: Niniejszy artykuł przedstawia znaczenie skaningu laserowego jako metody pozyskiwania danych przestrzennych oraz znaczenia tej metody podczas procesu inwentaryzacji obiektów zabytkowych. Autorzy tekstu skupiają się na badaniach inwentaryzacyjnych dotyczących poterny znajdującej się pod wschodnim zboczem Twierdzy Kłodzko i łączącej miasto z górnymi poziomami. Wykorzystując do czynności pomiarowych skaning laserowy uzyskano trójwymiarowy obraz poterny. Bazując na wykonanych pomiarach możliwe jest sprecyzowanie pomiarów dotyczących elementów tunelu o utrudnionej możliwości pomiaru jak np.: zasypanego fragmentu poterny oraz wysokości nasypu ziemnego zlokalizowanego nad tunelem. Przeprowadzone przez autorów tekstu badania zestawione zostały z dostępnymi materiałami archiwalnymi dotyczącymi tej części Twierdzy Kłodzko. 